\title{
Storage Studies on Quality Parameters in Nectar Prepared from Different Cultivars of Mango
}

\author{
Satish Kumar*, R.K. Godara, Suresh Kumar and Rahul Jhamb \\ Chaudhary Charan Singh Haryana Agricultural University, Hisar-125004, Haryana, India \\ *Corresponding author
}

\begin{tabular}{|l|}
\hline Ke y w o r d s \\
Nectar, Pulp, \\
$\begin{array}{l}\text { Storage and } \\
\text { cultivars }\end{array}$ \\
\hline Article Info \\
\hline $\begin{array}{l}\text { Accepted: } \\
\text { 07 January } 2018 \\
\text { Available Online: } \\
\text { 10 February } 2018\end{array}$ \\
\hline
\end{tabular}

\section{A B S T R A C T}

The experiment was conducted with four mango cultivars i.e. Dasherhari, Langra, S.B. Chausa and Amrapali in Fruit Technology Laboratory of the Department of Horticulture, CCS Haryana Agricultural University, Hisar to assess the storage of nectar at room temperature prepared from fresh mango pulp. The maximum TSS $(21.5 \%)$ was recorded in nectar prepared from cultivar S.B. Chausa and Acidity (0.294\%) in Langra and Amrapali. TSS content of nectar increased significantly from $20 \%$ on 0 day to $22.4 \%$ on 180 days of storage, irrespective of cultivar. Acidity content of nectar decreased significantly from $0.300 \%$ on 0 day to $0.284 \%$ on 180 days of storage, irrespective of cultivar. Total and reducing sugar content of nectar was increased with increase in storage period. Ascorbic acid and total carotenoid content decreased with increase in storage period. Maximum ascorbic acid $(18.87 \mathrm{mg} / 100 \mathrm{ml})$ and minimum $(8.83 \mathrm{mg} / 100 \mathrm{ml})$ was found in nectar prepared from Langra and Dashehari, respectively, irrespective of storage period. Maximum $(3.27 \mathrm{mg} / 100 \mathrm{ml})$ and minimum $(1.77 \mathrm{mg} / 100 \mathrm{ml})$ of carotenoid content was recorded in nectar prepared from Amrapali and S.B. Chausa, respectively, irrespective of storage period. Among the different cultivars, minimum organoleptic rating (6.1) in nectar prepared from Langra and maximum score (7.2) was observed in nectar prepared from Amrapali and Dashehari.

\section{Introduction}

Mango is the most popular fruit of India. It is also known as "King of Indian Fruits". Which is one of the most important tropical fruits commercialized and consumed worldwide fresh or processed, having an attractive colour and distinct taste and aroma (Singh et al., 2000). Mango is rich source of vitamin A, C and has recently been found to be high in anticancer antioxidants and phenols. The fruits contain carbohydrates (13.2 to $20.0 \mathrm{~g}$ ), proteins $(0.30$ to $0.80 \mathrm{~g})$, fat $(0.10$ to $0.27 \mathrm{~g})$, fibre $(0.60$ to $1.80 \mathrm{~g})$, vitamin $\mathrm{A}(765 \mathrm{mg})$, vitamin $\mathrm{C}$ (14 to $62 \mathrm{mg}$ ), minerals like potassium (156 mg), phosphorus (10 to 15 $\mathrm{mg})$, magnesium $(9 \mathrm{mg})$ and fair amount of iron $(0.10$ to $0.20 \mathrm{mg})$ and provides 225 to 350 KJ energy per $100 \mathrm{~g}$ of pulp (Janick and Paull, 2006). Post harvest losses of fruits and vegetables in our country are very high i.e. 20 to $30 \%$ every year (Saigal, 2001). However only $2 \%$ of the total production is used for processing, where as this figure is more than 
$50 \%$ in developed countries (Roy, 2001). Mangoes are classified as climacteric fruit and ripen quite rapidly after harvest. Disease problems, sensitivity to low temperature storage and the severe perishable nature of the fruit limit the transport of fresh fruit from the site of harvest to distance places (Lizada, 1993). These losses can be minimized by utilizing green fruits for making pickle or chutney or as a sundried acidifying condiment (AMCHUR) whereas ripe fruit is used for preserve, jam, squash etc. (Srivastva, 1998).

Several processed foods are prepared from mango in which nectar plays an important role which is mainly used during summer season as a beverage. Nectar a kind of ready-to-serve beverage, blended with sugar syrup and containing more pulp may catch good market on account of low cost of production, nutritional richness and easy to use.

In India mango nectar is very common than other fruits. Being available in plenty during the season of production, there is glut in the market. As a result, growers are forced to sell the produce at marginal price. Further, there is also a lot of spoilage during marketing of this warm season fruit due to high temperature and humidity. Keeping in view the above facts, the experiment was conducted to study the storage of mango nectar regarding cultivars and storage period.

\section{Materials and Methods}

The experiment was conducted to prepare nectar from four mango cultivars i.e. Dashehari, S.B. Chausa, Langra and Amrapali for 0 to 180 days storage. The recipe for preparation of nectar is $20 \%$ pulp, TSS $20 \%$ and $0.3 \%$ acidity. The observations were recorded by the following methods:

Total soluble solids of nectar were observed at ambient temperature by hand refractometer.
Total acids were estimated by Titration against N/10 sodium hydroxide (Ranganna, 1977).

Ascorbic acid content was determined by the method of A.O.A.C. (1990).

Sugars were determined by "The Ferricyanide Method" as suggested by Hulme and Narain (1931) with some modifications in the estimation.

Total carotenoids were estimated by the method of A.O.A.C. (1990).

Mango nectars were evaluated for colour, appearance, aroma, texture, taste, overall acceptability as method described (Ranganna, $1986)$ at monthly interval of storage period.

The data were tabulated and statistically analyzed as per the method described by Snedecor and Cochran (1980). The design for tabulation of data followed was factorial completely randomized design (C.R.D.) and the data collected under each study was subjected to statistical analysis.

\section{Results and Discussion}

Total soluble solids content of mango nectar significantly increased from $20.0 \%$ on 0 day to $22.4 \%$ on 180 days which was at par with TSS at 150 days during storage when considered irrespective of cultivar (Table 1). Among different cultivars, maximum TSS was recorded in nectar prepared from S.B. Chausa (21.5\%) which was at par with Dashehari and Amrapali. The minimum (21.0\%) TSS was observed in Langra. The increase in TSS content with the increase in storage period, irrespective of pulp content and cultivars may possibly be due to partial hydrolysis of polysaccharides like cellulose, starch and pectic substances into simple soluble substances. Similar trend in change of TSS was found in Karonda squash (Deen and 
Singh, 2012) and in blended squash of mango and aloe vera (Chaudhary et al., 2017).

Acidity content of mango nectar showed a decreasing trend during storage from $0.300 \%$ on 0 day to $0.284 \%$ on 180 days irrespective of cultivar (Table 2). Among different cultivars, maximum acidity $(0.294 \%)$ was recorded in Amrapali and Langra which was at par with Dashehari. The minimum $(0.291 \%)$ acidity was recorded in nectar prepared from S.B. Chausa. Among the interaction, maximum acidity $(0.300 \%)$ was observed on 0 day in all the cultivars. The minimum acidity $(0.280 \%)$ in S.B. Chausa and maximum $(0.287 \%)$ in Langra was observed on 180 days of storage. This reduction in acidity with the increase in storage period might be due to hydrolysis of polysaccharides and nonreducing sugars in the presence of organic acid. Kannan and Thirumaran (2001) also opined that reduction in acidity during storage might be due to chemical reaction taking place between organic acids and pigments.

The total sugar content of mango nectar was increased during storage from $15.72 \%$ on 0 day to $17.08 \%$ on 180 days which was at par with total sugar at 150 days irrespective of cultivar (Table 3). Among different cultivars, maximum (17.24\%) and minimum (15.67\%) content of total sugar was recorded in nectar prepared from Amrapali and Dashehari, respectively. The increase in total sugar content during storage might be due to hydrolysis of polysaccharides like pectin, starch etc. into simple sugars. This could be attributed to gradual inversion of non-reducing sugars (Jain et al., 1988). Similar trend in change of total sugar was found in Karonda squash (Deen and Singh, 2012). There was a significant increase in reducing sugar content of nectar from $7.54 \%$ on 0 day to $8.23 \%$ on 180 days of storage, irrespective of cultivar (Table 4). Among different cultivars, maximum $(8.25 \%)$ and minimum $(7.56 \%)$ content of reducing sugar was recorded in nectar prepared from Langra and S.B. Chausa, respectively, irrespective of storage period. Interaction among cultivar and storage was found non-significant.

Ascorbic acid content reduced significantly from $15.65 \mathrm{mg} / 100 \mathrm{ml}$ on 0 day to 9.84 $\mathrm{mg} / 100 \mathrm{ml}$ on 180 days of storage of mango nectar, irrespective of cultivar (Table 5). Among the different cultivars, maximum ascorbic acid $18.87 \mathrm{mg} / 100 \mathrm{ml}$ and minimum $8.83 \mathrm{mg} / 100 \mathrm{ml}$ was found in nectar prepared from Langra and Dashehari, respectively, irrespective of storage period. The decline in ascorbic acid content might be due thermal oxidation during processing and subsequent oxidation in storage and also may be presence of residual of oxygen in glass bottle.

Similar changes in ascorbic acid content was reported in watermelon nector (Doodnath and Badriel, 2000), in blended mango papaya nectar (Kalra et al., 1991), in bael fruit squash (Kaushik et al., 2002) and in jamun squash (Das, 2009). Decrease in ascorbic acid was also recorded in squash from guava-mango blends (Yadav et al., 2015).

A significant reduction in carotenoid content from $2.67 \mathrm{mg} / 100 \mathrm{ml}$ on 0 day to $2.19 \mathrm{mg} / 100$ $\mathrm{ml}$ on 180 days was observed with the increase in storage period, irrespective of cultivar (Table 6). Among the different cultivars, maximum $(3.27 \mathrm{mg} / 100 \mathrm{ml})$ and minimum $(1.77 \mathrm{mg} / 100 \mathrm{ml})$ of carotenoid content was recorded in nectar prepared from Amrapali and S.B. Chausa respectively, irrespective of storage period. This decrease in carotenoid content during storage was probably due to the effect of high temperature and enzyme activation on the pigments. Similar observation was made in papaya nectar (Aruna et al., 1997) and suggested that the decrease might be due to unstable and photosensitive nature. 
Table.1 Effect of storage on TSS (\%) of nectar of different cultivars

\begin{tabular}{|c|c|c|c|c|c|}
\hline Days & Dashehari & Langra & S.B.Chausa & Amrapali & Mean \\
\hline 0 & 20.0 & 20.0 & 20.0 & 20.0 & 20.0 \\
\hline 30 & 20.3 & 20.3 & 20.7 & 20.3 & 20.4 \\
\hline 60 & 20.7 & 20.7 & 21.0 & 20.7 & 20.8 \\
\hline 90 & 21.3 & 21.0 & 21.7 & 21.3 & 21.3 \\
\hline 120 & 21.7 & 21.3 & 22.0 & 21.7 & 21.7 \\
\hline 150 & 22.0 & 21.7 & 22.3 & 22.0 & 22.0 \\
\hline 180 & 22.3 & 22.0 & 22.7 & 22.7 & 22.4 \\
\hline Mean & 21.2 & 21.0 & 21.5 & 21.2 & \\
\hline $\mathrm{CD}$ at $5 \%$ & $\begin{array}{l}\text { Cultivar - } 0 \\
\text { Storage - } 0\end{array}$ & & & & \\
\hline
\end{tabular}

Table.2 Effect of storage on acidity (\%) of nectar of different cultivars

\begin{tabular}{|c|c|c|c|c|c|}
\hline Days & Dashehari & Langra & S.B.Chausa & Amrapali & Mean \\
\hline $\mathbf{0}$ & $\mathbf{0 . 3 0 0}$ & $\mathbf{0 . 3 0 0}$ & $\mathbf{0 . 3 0 0}$ & $\mathbf{0 . 3 0 0}$ & $\mathbf{0 . 3 0 0}$ \\
$\mathbf{3 0}$ & $\mathbf{0 . 3 0 0}$ & $\mathbf{0 . 3 0 0}$ & $\mathbf{0 . 3 0 0}$ & $\mathbf{0 . 3 0 0}$ & $\mathbf{0 . 3 0 0}$ \\
$\mathbf{9 0}$ & $\mathbf{0 . 2 9 6}$ & $\mathbf{0 . 2 9 7}$ & $\mathbf{0 . 2 9 6}$ & $\mathbf{0 . 2 9 7}$ & $\mathbf{0 . 2 9 6}$ \\
120 & $\mathbf{0 . 2 9 3}$ & $\mathbf{0 . 2 9 4}$ & $\mathbf{0 . 2 9 2}$ & $\mathbf{0 . 2 9 4}$ & $\mathbf{0 . 2 9 4}$ \\
150 & $\mathbf{0 . 2 9 1}$ & $\mathbf{0 . 2 9 1}$ & $\mathbf{0 . 2 8 8}$ & $\mathbf{0 . 2 9 1}$ & $\mathbf{0 . 2 9 0}$ \\
$\mathbf{1 8 0}$ & $\mathbf{0 . 2 8 7}$ & $\mathbf{0 . 2 8 9}$ & $\mathbf{0 . 2 8 3}$ & $\mathbf{0 . 2 8 8}$ & $\mathbf{0 . 2 8 7}$ \\
Mean & $\mathbf{0 . 2 8 3}$ & $\mathbf{0 . 2 8 7}$ & $\mathbf{0 . 2 8 0}$ & $\mathbf{0 . 2 8 5}$ & $\mathbf{0 . 2 8 4}$ \\
\hline CD at 5\% & $\mathbf{0 . 2 9 3}$ & $\mathbf{0 . 2 9 4}$ & $\mathbf{0 . 2 9 1}$ & $\mathbf{0 . 2 9 4}$ & \\
\hline
\end{tabular}

Table.3 Effect of storage on total sugars (\%) of nectar of different cultivars

\begin{tabular}{|c|c|c|c|c|c|}
\hline Days & Dashehari & Langra & S.B.Chausa & Amrapali & Mean \\
\hline $\mathbf{0}$ & 14.98 & 16.11 & 15.21 & 16.56 & 15.72 \\
$\mathbf{3 0}$ & 15.21 & 16.34 & 15.43 & 16.79 & 15.94 \\
60 & 15.44 & 16.56 & 15.65 & 17.02 & 16.17 \\
90 & 15.67 & 16.79 & 15.88 & 17.24 & 16.40 \\
120 & 15.89 & 17.01 & 16.11 & 17.47 & 16.62 \\
150 & 16.12 & 17.24 & 16.34 & 17.70 & 16.85 \\
180 & 16.34 & 17.47 & 16.57 & 17.92 & 17.08 \\
Mean & 15.67 & 16.79 & 15.89 & 17.24 & \\
\hline CD at 5\% & Cultivar - 0.20 & & & \\
\hline & Storage - 0.26 & & & \\
\hline
\end{tabular}


Table.4 Effect of storage on reducing sugars (\%) of nectar of different cultivars

\begin{tabular}{|c|c|c|c|c|c|}
\hline Days & Dashehari & Langra & S.B.Chausa & Amrapali & Mean \\
\hline $\mathbf{0}$ & $\mathbf{7 . 3 7}$ & $\mathbf{7 . 8 9}$ & $\mathbf{7 . 2 3}$ & $\mathbf{7 . 6 5}$ & $\mathbf{7 . 5 4}$ \\
$\mathbf{3 0}$ & $\mathbf{7 . 4 7}$ & $\mathbf{8 . 0 3}$ & $\mathbf{7 . 3 3}$ & $\mathbf{7 . 7 5}$ & $\mathbf{7 . 6 4}$ \\
$\mathbf{6 0}$ & $\mathbf{7 . 5 6}$ & $\mathbf{8 . 1 7}$ & $\mathbf{7 . 4 2}$ & $\mathbf{7 . 8 9}$ & $\mathbf{7 . 7 6}$ \\
$\mathbf{9 0}$ & $\mathbf{7 . 7 0}$ & $\mathbf{8 . 2 6}$ & $\mathbf{7 . 5 6}$ & $\mathbf{7 . 9 8}$ & $\mathbf{7 . 8 8}$ \\
$\mathbf{1 2 0}$ & $\mathbf{7 . 8 4}$ & $\mathbf{8 . 3 5}$ & $\mathbf{7 . 6 5}$ & $\mathbf{8 . 1 2}$ & $\mathbf{7 . 9 9}$ \\
$\mathbf{1 5 0}$ & $\mathbf{7 . 9 3}$ & $\mathbf{8 . 4 9}$ & $\mathbf{7 . 7 9}$ & $\mathbf{8 . 2 1}$ & $\mathbf{8 . 1 1}$ \\
$\mathbf{1 8 0}$ & $\mathbf{8 . 0 3}$ & $\mathbf{8 . 5 9}$ & $\mathbf{7 . 9 3}$ & $\mathbf{8 . 3 5}$ & $\mathbf{8 . 2 3}$ \\
Mean & $\mathbf{7 . 7 0}$ & $\mathbf{8 . 2 5}$ & $\mathbf{7 . 5 6}$ & $\mathbf{7 . 9 9}$ & \\
\hline CD at 5\% & Cultivar - 0.08 & & & \\
\hline
\end{tabular}

Table.5 Effect of storage on ascorbic acid (mg/100ml) of nectar of different cultivars

\begin{tabular}{|c|r|r|r|r|r|}
\hline Days & Dashehari & \multicolumn{1}{|c|}{ Langra } & S.B.Chausa & Amrapali & \multicolumn{1}{|c|}{ Mean } \\
\hline $\mathbf{0}$ & 11.50 & 22.35 & 13.83 & 14.90 & 15.65 \\
30 & 10.50 & 21.00 & 13.02 & 13.83 & 14.59 \\
60 & 9.33 & 19.97 & 12.17 & 12.92 & 13.60 \\
90 & 8.83 & 18.85 & 11.52 & 11.90 & 12.78 \\
120 & 8.00 & 17.67 & 10.33 & 10.87 & 11.72 \\
150 & 7.33 & 16.68 & 9.67 & 9.67 & 10.84 \\
180 & 6.33 & 15.60 & 8.57 & 8.87 & 9.84 \\
Mean & 8.83 & 18.87 & 11.30 & 11.85 & \\
\hline CD at 5\% & Cultivar - 0.46 & & & \\
& Storage - 0.60 & & & \\
\hline
\end{tabular}

Table.6 Effect of storage on carotenoid content $(\mathrm{mg} / 100 \mathrm{ml})$ of nectar of different cultivars

\begin{tabular}{|c|r|r|r|r|r|}
\hline Days & Dashehari & Langra & S.B.Chausa & Amrapali & Mean \\
\hline 0 & $\mathbf{2 . 4 5}$ & $\mathbf{2 . 6 5}$ & $\mathbf{2 . 0 5}$ & $\mathbf{3 . 5 5}$ & $\mathbf{2 . 6 7}$ \\
$\mathbf{3 0}$ & $\mathbf{2 . 3 5}$ & $\mathbf{2 . 5 5}$ & $\mathbf{1 . 9 5}$ & $\mathbf{3 . 4 5}$ & $\mathbf{2 . 5 7}$ \\
$\mathbf{6 0}$ & $\mathbf{2 . 2 7}$ & $\mathbf{2 . 4 5}$ & $\mathbf{1 . 8 5}$ & $\mathbf{3 . 3 5}$ & $\mathbf{2 . 4 8}$ \\
$\mathbf{9 0}$ & $\mathbf{2 . 1 9}$ & $\mathbf{2 . 4 7}$ & $\mathbf{1 . 7 7}$ & $\mathbf{3 . 2 7}$ & $\mathbf{2 . 4 2}$ \\
$\mathbf{1 2 0}$ & $\mathbf{2 . 1 1}$ & $\mathbf{2 . 3 9}$ & $\mathbf{1 . 6 7}$ & $\mathbf{3 . 1 9}$ & $\mathbf{2 . 3 4}$ \\
$\mathbf{1 5 0}$ & $\mathbf{2 . 0 5}$ & $\mathbf{2 . 3 1}$ & $\mathbf{1 . 5 7}$ & $\mathbf{3 . 1 1}$ & $\mathbf{2 . 2 6}$ \\
$\mathbf{1 8 0}$ & $\mathbf{1 . 9 9}$ & $\mathbf{2 . 2 5}$ & $\mathbf{1 . 5 1}$ & $\mathbf{2 . 9 9}$ & $\mathbf{2 . 1 9}$ \\
Mean & $\mathbf{2 . 2 0}$ & $\mathbf{2 . 4 4}$ & $\mathbf{1 . 7 7}$ & $\mathbf{3 . 2 7}$ & \\
\hline CD at 5\% & Cultivar - 0.03 & & & & \\
& Storage - 0.04 & & & \\
& Cultivar X Storage - N.S. & & &
\end{tabular}


Table.7 Effect of storage on organoleptic rating of nectar of different cultivars

\begin{tabular}{|c|c|c|c|c|c|}
\hline Days & Dashehari & Langra & S.B.Chausa & Amrapali & Mean \\
\hline $\mathbf{0}$ & $\mathbf{8 . 0}$ & $\mathbf{7 . 3}$ & $\mathbf{7 . 7}$ & $\mathbf{8 . 3}$ & $\mathbf{7 . 8}$ \\
$\mathbf{3 0}$ & 7.7 & $\mathbf{6 . 7}$ & $\mathbf{7 . 3}$ & $\mathbf{8 . 0}$ & $\mathbf{7 . 4}$ \\
$\mathbf{6 0}$ & 7.7 & $\mathbf{6 . 7}$ & $\mathbf{6 . 7}$ & $\mathbf{7 . 7}$ & $\mathbf{7 . 2}$ \\
$\mathbf{9 0}$ & $\mathbf{7 . 3}$ & $\mathbf{6 . 0}$ & $\mathbf{6 . 7}$ & $\mathbf{7 . 0}$ & $\mathbf{6 . 8}$ \\
$\mathbf{1 2 0}$ & $\mathbf{7 . 0}$ & $\mathbf{5 . 7}$ & $\mathbf{6 . 3}$ & $\mathbf{6 . 7}$ & $\mathbf{6 . 4}$ \\
$\mathbf{1 5 0}$ & $\mathbf{6 . 7}$ & $\mathbf{5 . 3}$ & $\mathbf{6 . 0}$ & $\mathbf{6 . 3}$ & $\mathbf{6 . 1}$ \\
$\mathbf{1 8 0}$ & $\mathbf{6 . 3}$ & $\mathbf{5 . 0}$ & $\mathbf{5 . 7}$ & $\mathbf{6 . 3}$ & $\mathbf{5 . 8}$ \\
Mean & $\mathbf{7 . 2}$ & $\mathbf{6 . 1}$ & $\mathbf{6 . 6}$ & $\mathbf{7 . 2}$ & \\
\hline
\end{tabular}

Loss of total carotenoids during storage was also observed in guava-papaya blended RTS, papaya RTS beverages (Tiwari, 2000) and in watermelon RTS beverages (Gowda and Jalali, 1995).

The organoleptic rating decreased from 7.8 on 0 day to 5.8 on 180 days of storage, irrespective of storage period (Table 7). Among the different cultivars, minimum rating (6.1) in nectar prepared from Langra and maximum rating (7.2) was observed in nectar prepared from Amrapali and Dashehari. This might be due to changes in chemical constituents or certain enzymatic and non-enzymatic changes in the beverages during storage. Similar decrease in organoleptic rating was also reported in squash from guava-mango blends (Yadav et al., 2015).

\section{References}

A.O.A.C. 1990. Official methods of Analysis. $15^{\text {th }}$ Edn. Association of Official Analytical Chemist, Washington, D. C.

Aruna, K., Vimala, V., Ciridhar, N. and Rao, D. G. 1997. Studies on preparation and storage of nectar prepared from papaya (Carica papaya L.). Beverage and Food World. 24 (1): 29-32.

Chaudhary, M.; Deen, B.; Gautam, D.K. and Mishra, K.K. 2017. Studies on development of squash from mango
(Mangifera indica L.) pulp and aloe vera (Aloe barbadensis Miller.) gel blend. International Journal of Current Microbiology and Applied Sciences, 6(7): 1962-1969.

Das, J.N. 2009. Studies on storage stability of jamun beverages. Indian Journal of Horticulture, 66 (4): 508-510.

Deen, B. and Singh, I.S. 2012. Development of Karonda (Carissa carandas L.) squash. Beverage and Food World, 39 (2): 37-39.

Doodnath, L. and Badriel, N. 2000. Processing and quality evaluation of Ready-to-serve watermelon nectars. Indian Food Packer. 54 (4): 71-78.

Gowda, I. M. D. and Jalali, S. 1995. Studies on juice making from watermelon fruits. Indian Food Packer. 49 (3): 33-41.

Hulme, A.C. and Narain, R. 1931. The ferricyanide method for determination of reducing sugars. A modification of Hagedorn-Jensen-Hanes technique. Biochemical Jounal, 25: 1051-56.

Jain, S.P.; Tripathi, V.K.; Ram, H.B. and Singh, S. 1988. Varietal suitability of litchi for squash making. Indian Food Packer, 42(1): 29-33.

Janick, J. and Paull, R.E. 2006. Mangifera indica Mango. The Encyclopeddia of fruit and nuts. pp. 15- 20.

Kalra, S. K., Tandon, D. K. and Singh, B. P. 1991. Evaluation of mango-papaya 
blended beverage. Indian Food Packer. 45 (1): 33-36.

Kannan, S. and Thirumaran, A.S. 2001. Studies on storage life of jamun products. Indian Food Packer, 55(6): 125-127.

Kaushik, R.A.; Yamdagni, R. and Sharma, J.R. 2002. Changes in quality parameters during processing and storage of processed bael (Aegle marmelos). Indian Food Packer, 56(1): 71-74.

Lizada, C. 1993. Mango. In: Seymour, G. B., Taylor, J. E. and Tucker, G. A. (eds.). Biochemistry of Fruit Ripening. Chapman and Hall, London. PP: 255271

Ranganna, S. 1977. Manual of Analysis of fruits and vegetable products. TataMcgraw Hill Publishing Co., Ltd., New Delhi.

Ranganna, S. 1986. A handbook of analysis of fruits and vegetable products. TataMcgraw Hill Publishing Co., Ltd., New Delhi.

Roy, S. K. 2001. Integrated post production management and food processing the national objective. Indian Food Packer, 55(2): 76-80.

Saigal, Omesh. 2001. Food processing industry current same and prospects. Indian Food Packer, 55(1): 88-91

Singh, N.I.; Dhuique-Mayer, C. and Lozano Y. 2000. Physico-chemical changes during enzymatic liquefaction of mango pulp (cv. Keitt). Journal of Food Processing and Preservation, 24(1): 7385.

Snedecor, G.W. and Cochran, W.G. 1980. Statistical methods. Oxford and IBH Publishing Co.

Srivastva, J. S. 1998. Mango Processing industry- A Scenario. Indian Food Packer, 52(6): 43-51.

Tiwari, R. B. 2000. Studies on blending of guava and papaya pulp for RTS beverage. Indian Food Packer. 54 (2): 68-72.

Yadav, S.; Gehlot, R.S.; Siddiqui, S. and Grewal, R. 2015. Development and evaluation of ready-to-serve (RTS) drink and squash from guava-mango blends. Beverage and Food World, 42(5): 47-50.

\section{How to cite this article:}

Satish Kumar, R.K. Godara, Suresh Kumar and Rahul Jhamb. 2018. Storage Studies on Quality Parameters in Nectar Prepared from Different Cultivars of Mango. Int.J.Curr.Microbiol.App.Sci. 7(02): 718-724. doi: https://doi.org/10.20546/ijcmas.2018.702.090 